\title{
Range Grasses and Their Small Grain Equiva- lents for Wind Erosion Control
}

\author{
LEON LYLES AND BRUCE E. ALLISON
}

\begin{abstract}
An equation that estimates potential wind erosion requires that all vegetative cover (dry weight per area) be expressed as a small grain equivalent. Wind-tunnel tests were used to determine that equivalent for selected range grasses, either as single species or mixtures, at three grazing-management levels. Compared with flat small grain, range grasses evaluated effectively prevented erosion, with buffalograss (Buchloe dactyloides) the most effective and big bluestem (Andropogon gerardi) the least effective among those tested. A possible procedure for extending the results to other grasses or mixtures is suggested. The data on range grass to small grain equivalent for erosion control may be used to predict the wind erosion potential of range sites or to determine the amounts of range grass needed to hold potential erosion to tolerable limits.
\end{abstract}

Managing vegetative cover is the most effective practical method for controlling wind erosion (Woodruff et al. 1977). Effectiveness of wind erosion control depends on the quantity, kind, and orientation of vegetation in relation to the soil surface (including areal distribution) (Chepil 1944; Siddoway et al. 1965; Lyles and Allison 1976). Current procedures for evaluating or designing management systems for wind erosion control utilize the following equation (Woodruff and Siddoway 1965):

$$
E=f(I, K, C . L . V),
$$

where $E$ is the potential annual soil-loss rate; $I$, the soil erodibility; $K$, the soil ridge roughness factor: $C$, the climatic factor; $L$, the unsheltered distance across a field along the prevailing wind erosion direction; and $V$, the equivalent vegetative cover. To use the equation, one must express all vegetative cover (dry weight per unit area) in terms of its equivalent to a small grain standard. The standard (reference) has been defined as $25.4 \mathrm{~cm}$ of dry small grain stalks lying flat on the soil surface in rows perpendicular to wind direction with 25.4-cm row spacing, with stalks oriented parallel to the wind direction.

Although equivalents data are available for several agronomic crops, none have been obtained for range grasses. Consequently, we initiated this study to determine the small grain equivalents of several perennial range grasses as single species or mixtures at three levels of simulated grazing management.

\section{Experimental Procedure}

Native perennial range grasses made available by the U.S. Dep.

Authors are agricultural engineer, Science and Education Administration, Agricultural Research, U.S. Department of Agriculture; and research assistant, Agronomy Department, Kansas State University, Manhattan, respectively.

This research is a contribution from the Sci. and Educ. Admin., Agr. Res., U.S. Dep. Agr., in cooperation with the Kansas Agricultural Experiment Station. Dep. of Agronomy Contribution No. 79-61-J.

Manuscript received December 28, 1978.
Agr., Soil Conservation Service, from ungrazed sites in Nebraska were buffalograss (Buchloe dactyloides), sideoats grama (Bouteloua curtipendula), western wheatgrass (Agropyron smithii), and needleandthread (Stipa comata). Big bluestem (Andropogon gerardi), little bluestem (Andropogon scoparius), switchgrass (Panicum virgatum), and blue grama (Bouteloua gracilis) were obtained from the Plant Materials Center, Manhattan, Kansas (Table 1). All grasses were harvested after dormancy with $5.1 \mathrm{~cm}$ of intact roots for anchoring. In the laboratory, the plants were washed and air-dried before wind-tunnel testing. Properly grazed and overgrazed management levels were simulated by clipping the ungrazed material to various heights (Table 1).

The wind-tunnel, $1.52 \mathrm{~m}$ wide, $1.93 \mathrm{~m}$ high, and $16.46 \mathrm{~m}$ long, was a recirculating push-type tunnel with airflow generated by a 10blade, variable-pitch axivane fan. The appropriate kind, amount, and height of grass was placed in standard test trays $148 \mathrm{~cm}$ long, 16.5 $\mathrm{cm}$ wide, and $4 \mathrm{~cm}$ deep (inside dimensions). The trays were then filled with sand 0.297 to $0.42 \mathrm{~mm}$ in diameter so that the grass stood in clumps, and were exposed for 5 minutes at $13.36 \mathrm{~m} / \mathrm{sec}$ freestream

Table 1. Heights of standing perennial range grasses that were evaluated in a wind tunnel at three levels of grazing management for wind-erosion protection.

\begin{tabular}{|c|c|c|c|c|}
\hline \multirow[b]{2}{*}{ Grass species } & \multicolumn{3}{|c|}{ Height (cm) } & \multirow[b]{2}{*}{ Symbol } \\
\hline & Ungrazed & $\begin{array}{c}\text { Properly } \\
\text { grazed }\end{array}$ & $\begin{array}{l}\text { Over- } \\
\text { grazed }\end{array}$ & \\
\hline \multicolumn{5}{|l|}{ Sod-forming grasses } \\
\hline $\begin{array}{l}\text { Big bluestem (Andropogon } \\
\text { gerardi) }\end{array}$ & 1 & $15.2^{2}$ & 2.5 & BB \\
\hline $\begin{array}{l}\text { Western wheatgrass } \\
\text { (Agropyron smithii) }\end{array}$ & 1 & 10.2 & 2.5 & ww \\
\hline $\begin{array}{l}\text { Buffalograss } \\
\text { (Buchloe dactyloides) }\end{array}$ & 10.2 & 5.1 & 2.5 & B \\
\hline \multicolumn{5}{|l|}{ Bunch grasses } \\
\hline $\begin{array}{l}\text { Switchgrass (Panicum } \\
\text { virgatum) }\end{array}$ & 1 & $15.2^{2}$ & 2.5 & \\
\hline $\begin{array}{l}\text { Little bluestem } \\
\text { (Andropogon scoparius) }\end{array}$ & 1 & 10.2 & 2.5 & \\
\hline $\begin{array}{l}\text { Blue grama } \\
\text { (Bouteloua gracilis) }\end{array}$ & 33.0 & 5.1 & 2.5 & \\
\hline \multicolumn{5}{|l|}{ Mixtures } \\
\hline Big bluestem ( $60 \%)$ & $\begin{array}{l}1 \\
1\end{array}$ & $15.2^{2}$ & 2.5 & $\mathbf{M}_{1}$ \\
\hline $\begin{array}{l}\text { Sideoats grama (Bouteloua } \\
\text { curtipendula })(10 \%)\end{array}$ & 1 & $\begin{array}{l}15.2 \\
15.2\end{array}$ & $\begin{array}{l}2.5 \\
2.5\end{array}$ & \\
\hline $\begin{array}{l}\text { Western wheatgrass (45\%) } \\
\text { Needleandthread (Stipa } \\
\text { comata) }(30 \%)\end{array}$ & $\begin{array}{l}43.2 \\
43.2\end{array}$ & $\begin{array}{l}10.2 \\
10.2\end{array}$ & $\begin{array}{l}2.5 \\
2.5\end{array}$ & $\mathbf{M}_{2}$ \\
\hline Blue grama $(25 \%)$ & 33.0 & 10.2 & 2.5 & \\
\hline $\begin{array}{l}\text { Blue grama ( } 45 \%) \\
\text { Buffalograss }(30 \%) \\
\text { Western wheatgrass }(25 \%)\end{array}$ & $\begin{array}{l}33.0 \\
10.2 \\
43.2\end{array}$ & $\begin{array}{l}5.1 \\
5.1 \\
5.1\end{array}$ & $\begin{array}{l}2.5 \\
2.5 \\
2.5\end{array}$ & $\mathbf{M}_{3}$ \\
\hline
\end{tabular}

'Species too tall to evaluate in wind tunnel.

2 Shorter than "properly grazed" for these two grasses. 


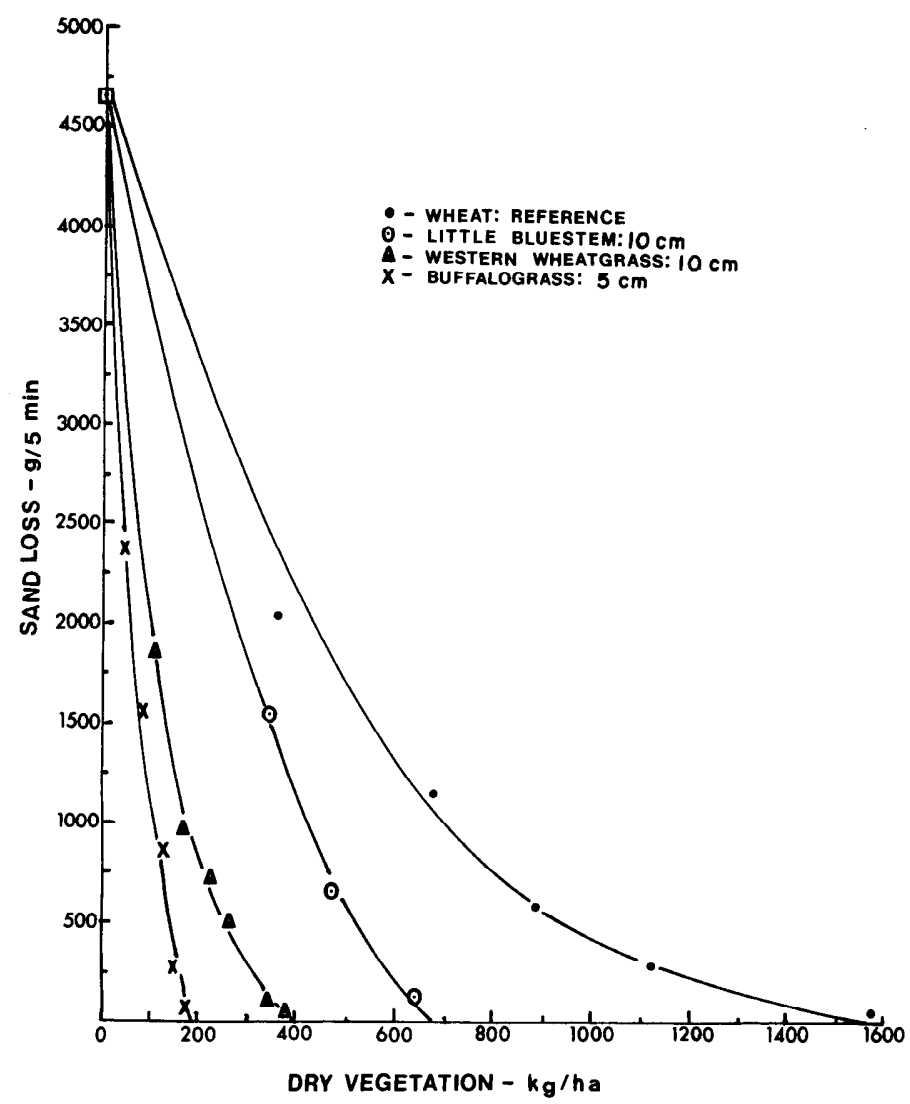

Fig. 1. Wind-tunnel sand loss as related to amount of standing vegetation for selected range grasses. Winter wheat is used as reference.

windspeed in the tunnel. Two test trays were located approximately $14.5 \mathrm{~m}$ downwind and $7 \mathrm{~cm}$ apart (side by side) during each exposure. The entire wind-tunnel floor area downwind and $4.9 \mathrm{~m}$ upwind from the test area was covered with the same number of grass "clumps" per unit area as the test trays contained. The sand loss was determined from the differences in tray plus sand weight before and after exposure to wind. Four to six runs for each single species or mixture at each height were conducted to establish a relationship between the sand-loss rate and the dry weight per unit area of the vegetation.

Small grain stubble (winter wheat) [displayed in the reference manner] was tested under the same conditions as the range grasses to provide the required data for determining their small grain equivalents.

\section{Results}

Typical curves of sand-loss rate as related to the amounts of dry vegetation for selected grasses and winter wheat (Fig. 1) and similar data for the other single grasses and mixtures for the three levels of grazing management were converted to an equivalent quantity of flat small grain residue as illustrated in Figure 2. We chose the abscissa as the dependent variable (small grain equivalent) and the logarithmic ordinate for the grasses to be converted, the method of plotting current charts used by the Soil Conservation Service. A power equation of the form

$(S G)_{e}=a X^{b}$

resulted in high simple-correlation coefficients $(r)$. In the power equation, $(S G)_{e}$ is the small equivalent and $X$ is the quantity of grass to be converted, both as $\mathrm{kg} / \mathrm{ha}$, and $a$ and $b$ are constants. Specific equation coefficients for each grass or

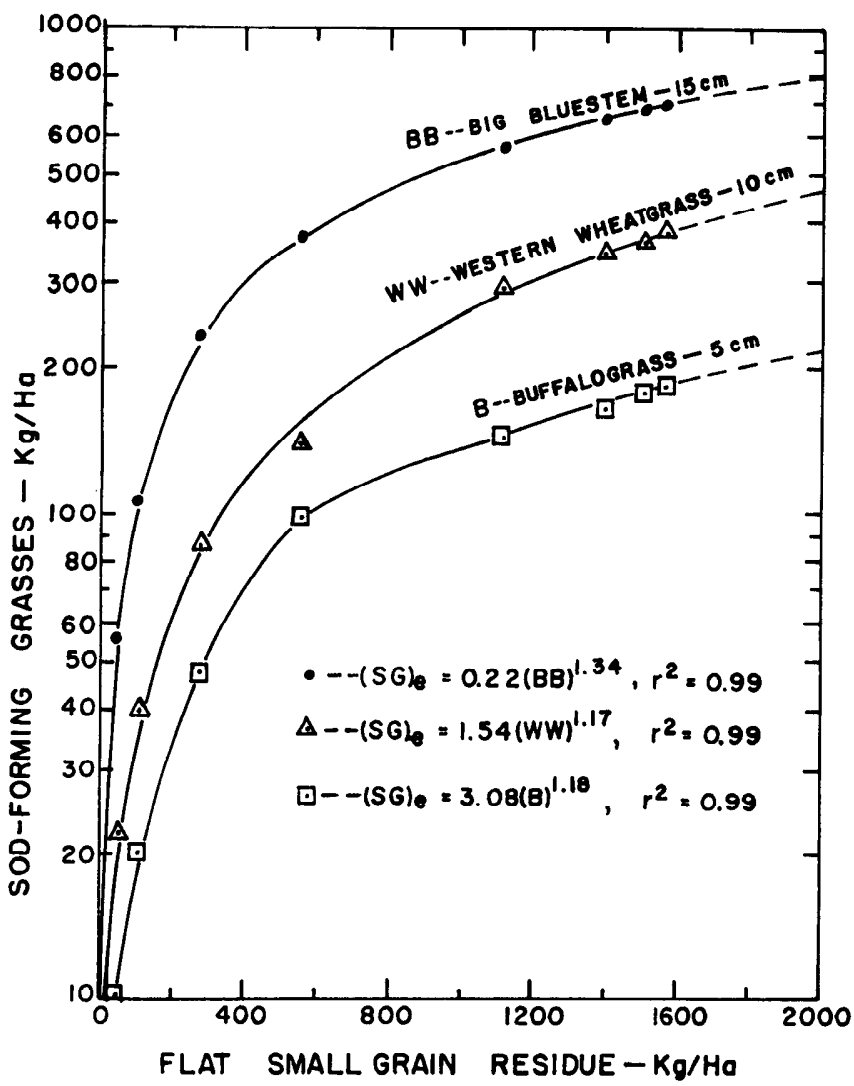

Fig. 2. Conversion of properly grazed big bluestem (see footnote 2 in Table 1), western wheatgrass, and buffalograss to equivalent quantity of flat small grain residue $\left[(S G)_{e}\right]$.

mixture and grazing level, and the corresponding $r^{2}$, are given in Tables 2 and 3.

Compared with the flat small grain, range grasses effectively prevented wind erosion. Buffalograss was the most effective and big bluestem the least effective among the grasses tested. For example, $150 \mathrm{~kg} / \mathrm{ha}$ of properly grazed buffalograss was equivalent to about $1,150 \mathrm{~kg} / \mathrm{ha}$ of flat small grain and $600 \mathrm{~kg} / \mathrm{ha}$ of properly grazed big bluestem was equivalent to about $1,200 \mathrm{~kg} / \mathrm{ha}$ of flat small grain (Fig. 2).

Table 2. Coefficients in prediction equation, $(\mathbf{S G})_{\mathrm{e}}=\mathbf{a} \mathbf{X}^{\mathbf{b}}$, for conversion of range grasses to equivalent quantity of flat, small grain residue (equation 2).

\begin{tabular}{lcccc}
\hline Grass species & \multicolumn{2}{c}{ Grazing } & \multicolumn{3}{c}{ Prediction } & equation coefficients \\
management & ${ }^{1}$ & $\mathrm{a}$ & $\mathrm{b}$ & $r^{2}$ \\
\hline Blue grama & Ungrazed & 0.60 & 1.39 & 0.98 \\
Buffalograss & Ungrazed & 1.40 & 1.44 & 0.97 \\
Big bluestem & Properly grazed & 0.22 & 1.34 & 0.99 \\
Blue grama & Properly grazed & 1.60 & 1.08 & 0.99 \\
Buffalograss & Properly grazed & 3.08 & 1.18 & 0.99 \\
Little bluestem & Properly grazed & 0.19 & 1.37 & 0.99 \\
Switchgrass & Properly grazed & 0.47 & 1.40 & 0.99 \\
Western wheat- & Properly grazed & 1.54 & 1.17 & 0.99 \\
$\quad$ grass & & & & \\
Big bluestem & Overgrazed & 4.12 & 0.92 & 0.99 \\
Blue grama & Overgrazed & 3.06 & 1.14 & 0.99 \\
Buffalograss & Overgrazed & 2.45 & 1.40 & 0.99 \\
Little bluestem & Overgrazed & 0.52 & 1.26 & 0.99 \\
Switchgrass & Overgrazed & 1.80 & 1.12 & 0.99 \\
Western wheat- & Overgrazed & 3.93 & 1.07 & 0.99 \\
grass & & & & \\
\hline
\end{tabular}

${ }^{1}$ See Table 1 for heights. 
Except for switchgrass, mixture 1, and mixture 2, the small grain equivalents for overgrazed grasses were greater for the same amount of plant material per area than for the properly grazed grasses (Tables 2 and 3 ). That was also generally true for the overgrazed as compared with the ungrazed grasses. These results do not suggest that overgrazing provides greater protection against wind erosion than does proper grazing or undergrazing! Under actual grazing, maintaining the same quantity of vegetation per unit area in overgrazed and properly grazed or ungrazed areas would be impossible because livestock consume most of the above-ground plant parts. In our wind-tunnel study, we increased the number of "plants" per unit area to make the quantities of overgrazed, properly grazed, and undergrazed grasses equal, because the properly grazed and ungrazed grasses were taller. Apparently, for these thin stands, the tendency for reduced plant height to increase erosion was more than offset by the stabilizing influence of more plants per unit area.

Table 3. Coefficients in prediction equation, $(S G)_{e}=a^{b}$, for conversion of range grass mixtures to equivalent quantity of flat, small grain residue (equation 2).

\begin{tabular}{ccccc}
\hline \hline $\begin{array}{l}\text { Grass } \\
\text { mixture }\end{array}$ & Grazing & \multicolumn{3}{c}{ Prediction equation coefficients } \\
management & $\mathrm{a}$ & $\mathrm{b}$ & $r^{2}$ \\
\hline $\mathrm{M}_{2}$ & Ungrazed & 0.29 & 1.30 & 0.99 \\
$\mathrm{M}_{3}$ & Ungrazed & 1.48 & 1.23 & 0.99 \\
$\mathrm{M}_{1}$ & Properly grazed & 4.21 & 0.94 & 0.99 \\
$\mathrm{M}_{2}$ & Properly grazed & 6.16 & 0.94 & 0.99 \\
$\mathrm{M}_{3}$ & Properly grazed & 5.39 & 0.97 & 0.99 \\
$\mathrm{M}_{1}$ & Overgrazed & 1.50 & 1.06 & 0.99 \\
$\mathrm{M}_{2}$ & Overgrazed & 1.64 & 1.17 & 0.99 \\
$\mathrm{M}_{3}$ & Overgrazed & 2.34 & 1.32 & 0.99 \\
\hline
\end{tabular}

${ }^{1}$ See Table 1 for mixture composition.

\section{Discussion}

Because only small quantities of grasses are required to reduce erosion to low values in the wind tunnel, measured field amounts of grasses generally will exceed the maximum values we evaluated, and will also exceed the upper limit used to determine equation [2]. We could safely say that there is no wind erosion hazard if the amounts of grasses in the field greatly exceed those indicated in Figure 2. If a small grain equivalent is desired for tall grasses, the field sample could be clipped to the properly grazed height before determining areal dry weight.
Concerning grass mixtures, two questions are important: (1) are the results using grass mixtures similar to the weighted effects of the single species making up the mixtures, and (2) how do we evaluate grass mixtures (or single species) other than those tested, either for the same or for different percentages? Only in mixture 3 (blue grama, buffalograss, and western wheatgrass) did we also test all the mixture grasses separately. Equation [3] may be expressed on a weighted basis:

$$
(S G)_{\mathrm{e}}=a_{1}{ }^{\mathrm{P}_{1}} a_{2}{ }^{\mathrm{P}} \ldots a_{\mathrm{n}}{ }^{\mathrm{P}_{\mathrm{n}}} \times{ }^{\mathrm{P}_{1} \mathrm{~b}_{1}+\ldots+\mathrm{P}_{\mathrm{n}} \mathrm{b}_{\mathrm{n}}}
$$

where $n$ is the number of grasses in a mixture, $P$ is the proportion of each grass (by weight) in a mixture, and $X$ is the total dry weight of the mixture per unit area. If $n=1$, i.e. a single species, then equation [3] becomes equation [2].

For mixture 3, agreement between the mixture equation and the weighed equation was good for the properly grazed level but only fair for the ungrazed and overgrazed levels (Table 4). The ratios in Table 4 for mixture 3 suggest that as height decreases, grasses in this mixture become more effective in reducing erosion than the weighting of their single effects suggests. Perhaps this mixture, as height decreases, is dominated by buffalograss - the most effective of all grasses tested in preventing erosion. When overgrazed, buffalograss has been reduced no more than $7.6 \mathrm{~cm}$ from the ungrazed height, but blue grama and western wheatgrass have been reduced 30.5 and $40.6 \mathrm{~cm}$, respectively. The weighted approach could be extended to mixture 3 grasses at percentages different from those tested.

The best approach to evaluating other grasses, of course, would be to test them in a wind tunnel. The large number of grasses makes that unlikely in the near future. Lacking experimental data, a range specialist or agronomist and scientist group could make composite judgments about which tested grass is most similar physically to an untested grass. Data for the tested grass than could be used for the grass in question. We used that approach by assuming sideoats grama in mixture 1 and needleandthread in mixture 2 were similar to western wheatgrass (Table 4). The results were fair to poor, depending on mixture and grazing level. The reasons for disagreement of equation [2] and equation [3] for those mixtures $\left(M_{1}\right.$ and $\left.M_{2}\right)$ are not clear. Experimental error and/or lack of similarity of the two grasses (sideoats grama and needleandthread) to western wheatgrass were assumed as explanations. However, errors of 18 to $41 \%$ in the small grain

Table 4. Comparison of small grain equivalents for three range grass mixtures at various levels of grazing management using mixture equation [2] and weighted equation [3].

\begin{tabular}{|c|c|c|c|c|c|c|}
\hline \multirow[b]{2}{*}{ Grass mixture ${ }^{1}$} & \multirow[b]{2}{*}{ Management level } & \multirow[b]{2}{*}{ Total dry weight } & \multicolumn{2}{|c|}{ Small grain equivalent } & \multirow{2}{*}{$\begin{array}{c}\text { Ratio } \\
\text { Eqn [2]/Eqn [3] }\end{array}$} & \multirow[b]{2}{*}{ Error } \\
\hline & & & Eqn [2] & Eqn [3] & & \\
\hline & & $\mathrm{kg} / \mathrm{ha}$ & $\mathrm{kg} / \mathrm{ha}$ & $\mathrm{kg} / \mathrm{ha}$ & & $\%$ \\
\hline $\mathbf{M}_{3}$ & Ungrazed & 300 & 1649 & $2163^{2}$ & 0.76 & 31 \\
\hline $\mathbf{M}_{3}^{\prime \prime}$ & Properly grazed & 300 & 1363 & 1232 & 1.11 & 10 \\
\hline $\mathbf{M}_{3}$ & Overgrazed & 150 & 1744 & 1248 & 1.40 & 28 \\
\hline $\mathbf{M}_{1}^{3}$ & Properly grazed & 500 & 1450 & $1007^{3}$ & 1.44 & 31 \\
\hline $\mathbf{M}_{1}$ & Overgrazed & 500 & 1089 & $1387^{3}$ & 0.79 & 27 \\
\hline $\mathbf{M}_{2}$ & Properly grazed & 300 & 1312 & $1082^{4}$ & 1.21 & 18 \\
\hline $\mathbf{M}_{2}^{2}$ & Overgrazed & 300 & 1297 & $1824^{4}$ & 0.71 & 41 \\
\hline
\end{tabular}

\footnotetext{
' See Table 1 for mixture composition.

${ }^{2}$ Properly grazed data was used for western wheatgrass.

${ }^{3}$ Sideoats grama was assumed similar to western wheatgrass.

${ }^{4}$ Needleandthread was assumed similar to western wheatgrass.
} 
equivalents when grasses were substituted may be acceptable for estimating wind erosion on range, pasture, and hay sites, especially if no experimental data are available.

Hopefully, these guides for calculating the small grain equivalents of range grasses will be useful to conservationists, environmentalists, and others. With a wind erosion equation (Woodruff and Siddoway 1965), the guides can be used to estimate the wind erosion potential of range, pasture, and hay sites and to determine the approximate amounts of grass needed to hold potential erosion to tolerable levels.

\section{Literature Cited}

Chepil, W.S. 1944. Utilization of crop residues for wind erosion control. Sci. Agr. 24(7):307-319.

Lyles, Leon, and Bruce E. Allison. 1976. Wind erosion: the protective role of simulated standing stubble. Trans. Amer. Soc. Agr. Engin. 19:61-64.

Siddoway, F.H., W.S. Chepil, and D.V. Armbrust. 1965. Effect of kind, amount, and placement of residue on wind erosion control. Trans. Amer. Soc. Agr. Engin. 8:327-331.

Woodruff, N.P., and F.H. Siddoway. 1965. A wind erosion equation. Soil Sci. Soc. Amer. Proc. 29:602-608.

Woodruff, N.P., Leon Lyles, F.H. Siddoway, and D.W. Fryrear. 1977. How to control wind erosion. U.S. Dep. Agr., Agr. Res. Serv., Agr. Inf. Bull. No. 354, 22 p. 